\title{
Performance and Emissions of a Single Cylinder CI Engine Running on Corn Oil Methyl Ester-Diesel Blends
}

\author{
Abdülvahap Çakmak and Atilla Bilgin
}

\begin{abstract}
This document presents an experimental study on performance and emissions of a single cylinder, direct injection CI engine fueled with corn oil methyl ester-diesel blends. The blend fuels contain corn oil methyl ester with ratios of $10 \%$ (B10), $20 \%$ (B20) and $50 \%$ (B50) on volume basis, respectively. Engine experiments were carried out an existing test unit for five different engine speeds at full throttle position. The results showed a reduction in engine torque and brake specific fuel consumption (BSFC) with increasing biodiesel percentage in the blend fuels except for B10. Blend fuels result in higher thermal efficiency than diesel fuel. The mean thermal efficiency of the engine by using diesel, B10, B20 and B50 were determined as $37.57 \%, 38.95 \%, 38.19 \%$ and $38.22 \%$, respectively. Also, blend fuels gave less $\mathrm{CO}$ and $\mathrm{O}_{2}$ emissions but higher $\mathrm{NO}_{x}, \mathrm{HC}$ and $\mathrm{CO}_{2}$ emissions compared to diesel fuel. It was calculated that $\mathrm{NO}_{x}$ emissions of B10, B20 and B50 were 16.25, 9.48 and $38.84 \%$ higher than diesel fuels, respectively.
\end{abstract}

Index Terms - CI engine, corn oil methyl ester-diesel blends, engine performance, emissions.

\section{INTRODUCTION}

The limited reserves of the fossil fuels, their increasing cost and a major contribution to the emission of combustion-generated pollutant have led biofuels more attractive [1]. Among the biofuels, biodiesel is the most appropriate alternative fuel because of its good fuel properties, engine performance, and emissions and it's substitution for diesel fuel in a diesel engine without any engine modification. Biodiesel can be produced from edible and non-edible vegetable oils, animal fats and waste oils. Biodiesel is non-toxic, biodegradable and environmentally friendly fuel [2]. Hence, production and consumption of the biodiesel have increased day by day, over the world. The EU is the world's largest biodiesel producer. Biodiesel is also the most important biofuel in the EU and, on energy basis, represents about 80 percent of the total transport biofuels market [3]. In the EU biodiesel consumption reached 13,060 million litters in 2015 [3]. In Turkey, Energy Market Regulatory Authority made it compulsory to blend domestically produced biodiesel to diesel fuel at least 3\% by the January $1^{\text {st }}, 2016$.

Several authors have published works about investigation engine performance and emission of a diesel engine fueled with biodiesel which produced different feedstock and/or biodiesel-diesel blends. Generally, these studies point out that by using biodiesel or its blends with diesel fuel result less

Manuscript received March 30, 2016; revised June 3, 2016.

Abdülvahap Çakmak is with Ondokuz Mayıs University, Turkey (e-mail: abdulvahap.cakmak@omu.edu.tr)

Atilla Bilgin is with Karadeniz Technical University, Turkey (e-mail: bilgin@ktu.edu.tr). engine performance, higher BSFC and a considerable reduction in $\mathrm{HC}, \mathrm{CO}$ and $\mathrm{PM}$ emissions, but an increase $\mathrm{NO}_{\text {, }}$ emissions in compared to diesel fuel [4]-[7].

In this study, corn oil is chosen as a raw material for biodiesel production which is abundant in Black Sea Region of Turkey and also it has a potential to be used as feedstock for biodiesel production in Turkey. Therefore, it needs to be determined the effects of corn oil biodiesel-diesel blends on a diesel engine's performance and exhaust emissions.

Authors are willing to contribute to the literature by investigation the influence of corn oil methyl ester-diesel blends on engine performance and emissions.

\section{EXPERIMENTAL EQUIPMENT AND TEST PROCEDURE}

Experiments were conducted on existing experimental setup at the Mechanical Engineering Department of Karadeniz Technical University. The experimental setup consists of a diesel engine, an engine test bed and a gas analyzer. A schematic view of the experimental setup is shown in Fig. 1. The engine used in this experiment was a single cylinder, natural aspirated, direct injection diesel engine with a cylinder bore of $88 \mathrm{~mm}$, a stroke of $76 \mathrm{~mm}$ and a compression ratio of 20.5:1. The maximum power of the test engine is $7.3 \mathrm{~kW}$ at $3600 \mathrm{rpm}$. There is not any modification of the diesel engine. The experimental setup enables accurate measurement of engine torque, engine speed, air mass flow rate, fuel volume flow rate and all the relevant temperatures and pressures. Exhaust gasses were measured by Bilsa MOD 2210 gas analyzer. Measurements range and accuracies of the gas analyzer are given in Table I. Engine tests were performed for five different engine speeds, namely $1000,1500,2000,2500$ and $3000 \mathrm{rpm}$ at full throttle position. Test data were recorded by versatile data acquisition system with a 0.5 -second interval during 10 seconds and the mean values of the data were used for calculations. All measurements are conducted under steady state conditions. Accuracies of the measurements and the uncertainties in the calculated result are given in Table II.

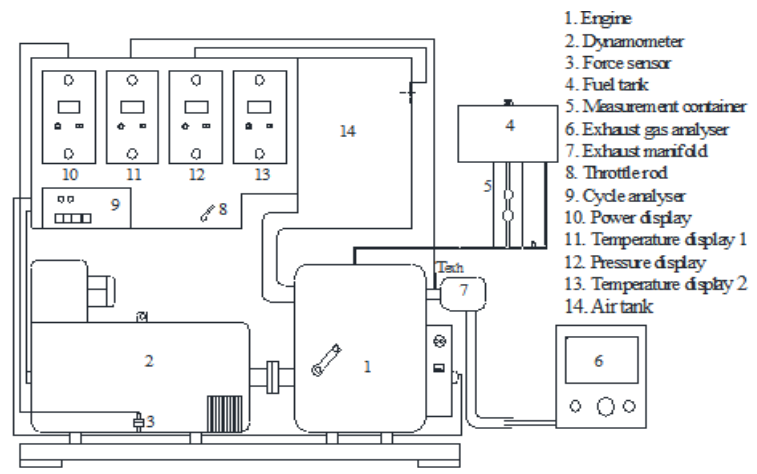

Fig. 1. A schematic view of the experimental setup. 
Biodiesel (corn oil methyl ester) was produced in the laboratory with biodiesel production machine from corn oil by a transesterification reaction with methanol $\left(\mathrm{CH}_{3} \mathrm{OH}\right)$, where potassium hydroxide $(\mathrm{KOH})$ was used as a catalyst. The reaction parameters giving the lowest kinematic viscosity were chosen as $1.1 \%$ catalyst concentration, $60{ }^{\circ} \mathrm{C}$ reaction temperature, 60 minutes reaction time and 9:1 alcohol/oil molar ratio [8]. Diesel fuel (Euro diesel) was purchased from a commercial supplier. Produced corn oil biodiesel was then mixed with diesel fuel by ratios of 10, 20 and $50 \%$ by volume designated as B10, B20 and B50, respectively. Some important properties of the test fuels such as density (ISO 4787), kinematic viscosity (DIN 53015), flash point temperature (EN ISO 3679) and lower heating value (DIN 51900-2) were measured in the Prof. Dr. Saadettin GUNER Fuel Research and Application Center at Karadeniz Technical University. Some fuel properties of the test fuels are shown in Table III.

TABLE I: SPECIFICATION OF EXHAUST GAS ANALYSER

\begin{tabular}{lcc}
\hline \hline Emissions & Measuring Range & Accuracy \\
\hline $\mathrm{CO}$ & $0-10 \%$ vol. & $0.001 \%$ \\
$\mathrm{CO}_{2}$ & $0-20 \%$ vol. & $0.001 \%$ \\
$\mathrm{HC}$ & $0-10000 \mathrm{ppm}$ & $1 \mathrm{ppm}$ \\
$\mathrm{O}_{2}$ & $0-25 \%$ vol. & $0.01 \%$ \\
$\mathrm{NO}_{x}$ & $0-5000 \mathrm{ppm}$ & $1 \mathrm{ppm}$ \\
\hline \hline
\end{tabular}

TABLE II: ACCURACIES OF THE MEASUREMENTS AND THE UNCERTAINTIES IN THE CALCULATED RESULT

\begin{tabular}{lc}
\hline \hline Measurements & Accuracy \\
\hline Engine speed & $\mp 1 \mathrm{rpm}$ \\
Engine torque & $\mp 0.1 \mathrm{Nm}$ \\
Temperature & $\mp 0.1^{\circ} \mathrm{C}$ \\
Calculated results & Uncertainty \\
BSFC & $\mp 0.6694 \%$ \\
Thermal efficiency & $\mp 0.7065 \%$ \\
\hline \hline
\end{tabular}

TABLE III: SOME FUEL PROPERTIES OF THE TEST FUELS

\begin{tabular}{|c|c|c|c|c|}
\hline Properties & Diesel & B10 & B20 & B50 \\
\hline $\begin{array}{l}\text { Density at } 20^{\circ} \mathrm{C}, \\
{\left[\mathrm{kg} / \mathrm{m}^{3}\right]}\end{array}$ & 826.379 & 831.767 & 836.357 & 852.322 \\
\hline $\begin{array}{l}\text { Kinematic } \\
\text { viscosity at } 40^{\circ} \mathrm{C} \text {, } \\
{\left[\mathrm{mm}^{2} / \mathrm{s}\right]}\end{array}$ & 2.8475 & 2.9326 & 2.9781 & 3.2342 \\
\hline Flash Point, ${ }^{\circ} \mathrm{C}$ & 63 & 74 & 90 & - \\
\hline $\begin{array}{l}\text { Lower heating } \\
\text { value, }[\mathrm{kJ} / \mathrm{kg}]\end{array}$ & 42797 & 42224 & 41697 & 40048 \\
\hline $\begin{array}{l}\text { Lower heating } \\
\text { value, }[\mathrm{kJ} / \mathrm{L}]\end{array}$ & 35367 & 35119 & 34874 & 34134 \\
\hline
\end{tabular}

\section{RESULTS AND DISCUSSIONS}

Fig. 2 shows the variation of engine torque with respect to engine speed for test fuels. It is seen from the figure that engine torque increase with increasing engine speed up to $2000 \mathrm{rpm}$, after $2000 \mathrm{rpm}$ increasing the engine speed leads to a decrease engine torque, because of an increase in mechanical friction and a decrease in volumetric efficiency. Diesel fuel which has higher heating value than other fuels gives slightly higher torque output than the B20 and B50, generally. On average, the engine torque values are determined as 21.71, 21.75, 21.27 and $21.5 \mathrm{Nm}$ for diesel, B10, B20 and B50, respectively. Although, the volume-based heating value of the diesel fuel is $0.71 \%, 1.41 \%$ and $3.61 \%$ higher than those of B10, B20 and B50, respectively, the torque value of the blends are very close to that diesel. The reason of this can be attributed to the oxygen content of the blend fuels which improve combustion efficiency and results in nearly the same engine torque output.

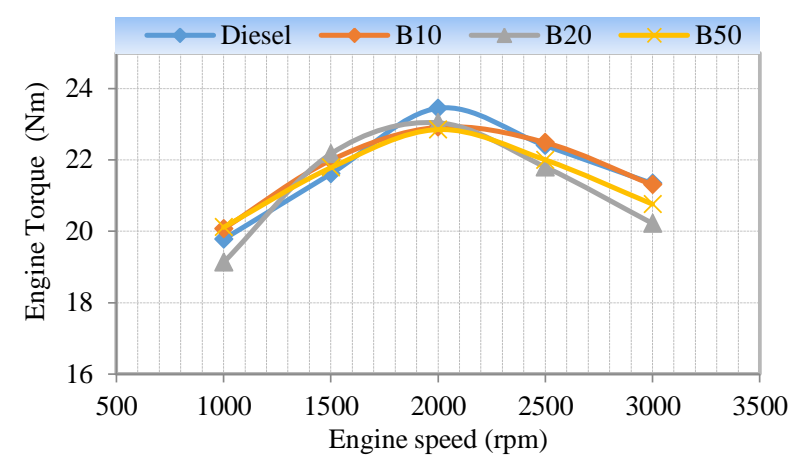

Fig. 2. Comparison of the engine torque for test fuels.

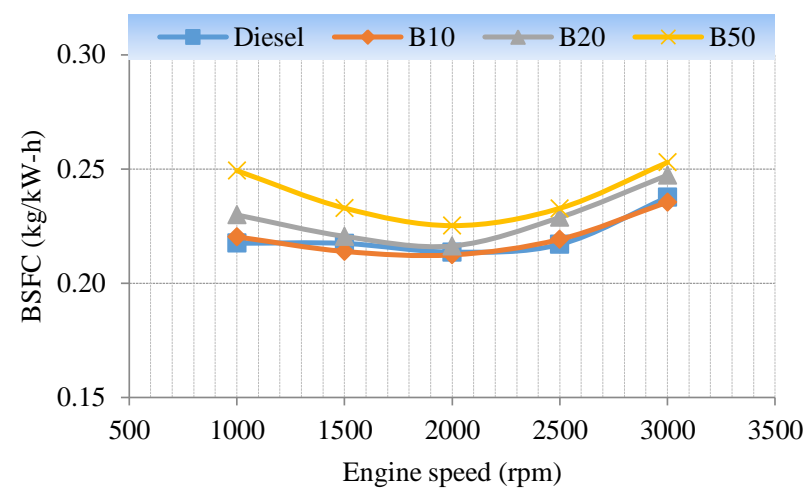

Fig. 3. Comparison of the BSFC for test fuels.

Brake specific fuel consumption (BSFC) is one of the basic performance characteristics used for comparing the effects of different fuel on engine performance [2]. The variation of BSFC for test fuels is illustrated in Fig. 3. As seen in the figure, the BSFC decrease with increasing the engine speed thanks to an increase in-cylinder turbulence [9] and fuel injection pressure which improve fuel-air mixture formation and this could be effective on decrease BSFC [5]. For diesel, $\mathrm{B} 10, \mathrm{~B} 20$ and B50 the minimum BSFC are obtained at 2000 $\mathrm{rpm}$ as $0.2136,0.2124,0.2163$ and $0.2252 \mathrm{~kg} / \mathrm{kW}-\mathrm{h}$, respectively. At high engine speeds the higher mechanical frictions and less time for combustion cause an increase in BSFC. The BSFC values of biodiesel-diesel blends are higher than those of diesel fuel except B10. The increase in BSFC is expected since the heating values of the blend fuels are lower than those of diesel fuel as given in Table II. But, by using B10 the oxygen content and the lower viscosity (when compared to B20 and B50) of it may be the reasons of the minimum BSFC. On average, the BSFC values are determined as $0.221,0.220,0.229$ and $0.239 \mathrm{~kg} / \mathrm{kW}-\mathrm{h}$ for diesel, B10, B20 and B50, respectively. In fact, the differences in BSFC values between diesel and B10 are negligible.

Fig. 4 shows the variation of exhaust temperature with respect to engine speed for test fuels. Exhaust temperatures of the test fuels increase with increasing engine speed due to more fuel consumption and shorter combustion duration at 
high engine speeds. Variation of the exhaust temperature for test fuels can be originated from the compositions of them. It is decelerated that biodiesel usually contains some constituents which have higher boiling temperatures and these constituents cannot evaporate completely during the main combustion phase but continue to burn in the late of combustion phase that causes a higher exhaust temperature [10]. On average, the exhaust temperature of B10, B20 and B50 were determined as $419.2^{\circ} \mathrm{C}, 425.2^{\circ} \mathrm{C}, 434.4^{\circ} \mathrm{C}$ and $428.2^{\circ} \mathrm{C}$, respectively. That is $\mathrm{B} 20$ gives maximum exhaust temperature while diesel fuel yields minimum exhaust temperature. As seen from here, exhaust temperature for blends fuels is not proportional to biodiesel contents in the blends fuel. This may attribute to different combustion characteristic of each fuel. A similar result can be found in the reference [11].

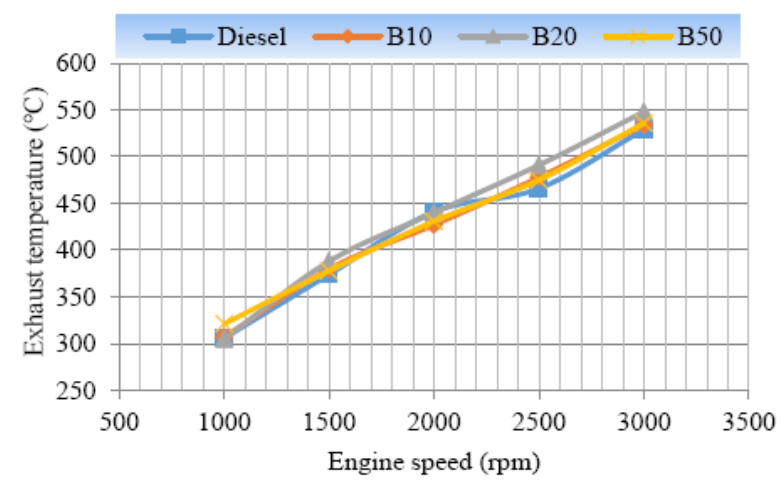

Fig. 4. Comparison of the exhaust temperature for test fuels.

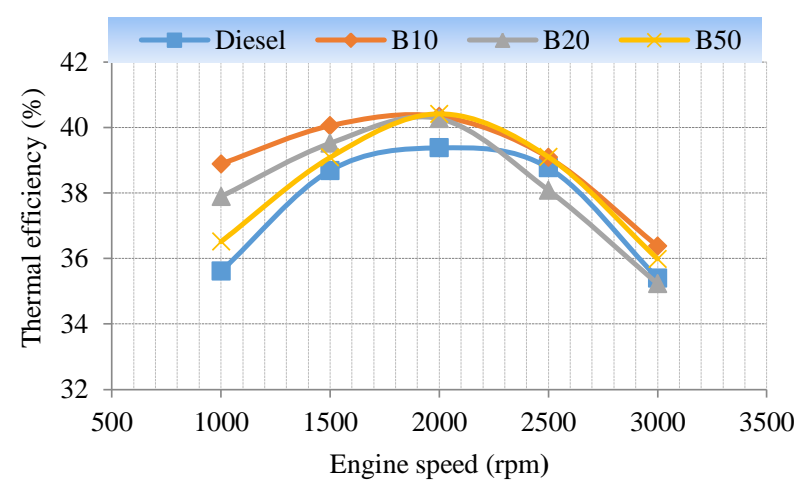

Fig. 5. Comparison of the thermal efficiency for test fuels.

The brake thermal efficiency of the engine for test fuels is shown in Fig. 5. The brake thermal efficiency is defined as the ratio of the net power output to fuel energy rate enters in the cylinder. As seen in Fig. 5 biodiesel-diesel blends gave higher thermal efficiency than diesel fuel, nearly all engine speed. This means that the engine converts the fuel energy to more effective power when operated with biodiesel-diesel blends. The oxygen content of blend fuels improve combustion phase and hence more fuel energy can be converted to power. Also, good lubricity property of the biodiesel affects the thermal efficiency positively. On average, the thermal efficiency of the engine by using diesel, $\mathrm{B} 10, \mathrm{~B} 20$ and B50 were determined as $37.57 \%$, 38.95\%, $38.19 \%$ and $38.22 \%$, respectively. Maximum thermal efficiency is obtained by B10 because that positive effect of the oxygen content and the negative effect of the high viscosity of the biodiesel result in an optimum biodiesel-diesel blend ratio, namely B10. By increasing the biodiesel percentage, the negative effect of the high viscosity of the biodiesel became more dominant than the positive effect of the oxygen content and good lubricity property of the biodiesel. As a result, at high biodiesel ratios, the thermal efficiency of the engine decreases.

Average exhaust emissions for test fuels are shown in Fig. 6-Fig. 10. Emissions emitted from the compression ignition engines are mostly dependent on air-fuel ratio, fuel type, combustion chamber design, the rate of atomization, start of injection timing, engine load and speed [12]. The variation of $\mathrm{CO}$ and $\mathrm{HC}$ emissions for test fuel are presented in Fig. 6 and Fig. 7, respectively. Not only $\mathrm{CO}$ and $\mathrm{HC}$ emissions have a serious impact on the environment and human health, but also, they represent lost chemical energy. $\mathrm{CO}$ emissions for $\mathrm{B} 10$ and B50 are $3.09 \%$ and $21.69 \%$ lower than diesel, respectively, but $\mathrm{CO}$ emission for $\mathrm{B} 20$ is $1.4 \%$ higher when compared to diesel fuel. As seen in Fig. 7, HC emissions for blend fuels are higher than diesel fuel. Average $\mathrm{HC}$ emission for diesel, B10, B20 and B50 were determined as 6.4, 9.7, $15.4,16.6 \mathrm{ppm}$, respectively. It is estimated that higher viscosity and fuel consumption of the blend fuels result in more $\mathrm{HC}$ emission than diesel fuel operation. Additionally, biodiesel consist of different components which have a different boiling point and these components cannot evaporate and burn fully. Hence, more $\mathrm{HC}$ emissions may be emitted from the engine when using biodiesel-diesel blends.

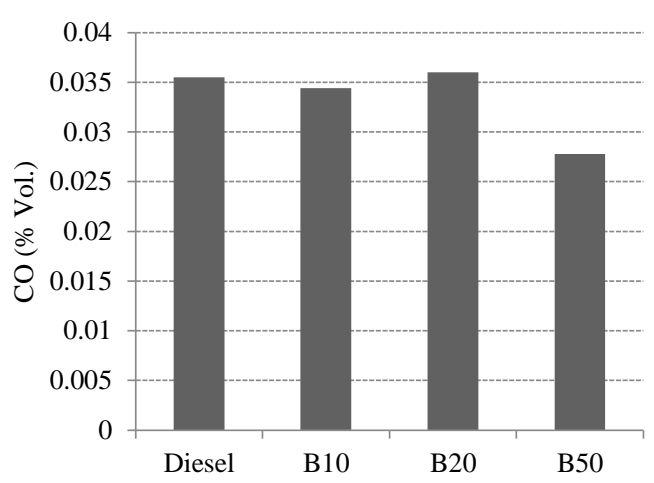

Fig. 6. Comparison of the $\mathrm{CO}$ emissions for test fuels.

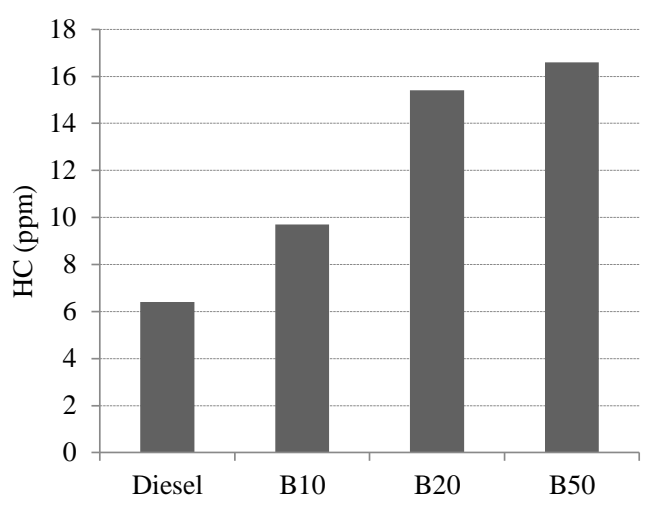

Fig. 7. Comparison of the HC emissions for test fuels.

Fig. 8 shows the $\mathrm{NO}_{x}$ emissions of the test fuels. As seen in the figure, blend fuels emitted more $\mathrm{NO}_{x}$ emissions when compared to diesel fuel. It is calculated that $\mathrm{NO}_{x}$ emissions of $\mathrm{B} 10, \mathrm{~B} 20$ and $\mathrm{B} 50$ are $16.25,9.48$ and $38.84 \%$ higher than diesel fuels, respectively. The reasons for the higher $\mathrm{NO}_{x}$ 
emissions for blend fuels may be oxygen content of the biodiesel. Additionally, higher viscosity, higher density and lower compressibility of the biodiesel cause an advance start of injection timing which increases $\mathrm{NO}_{x}$ emissions [4]. Therefore, by advancing the start of injection timing through the use of blend fuels could produce more $\mathrm{NO}_{x}$ emission than diesel fuel. Variation of the $\mathrm{CO}_{2}$ emissions for test fuels is shown in Fig. 9. $\mathrm{CO}_{2}$ emission is a product of the complete combustion but it is a greenhouse gas and has been limited in many countries. The main ways to reduce $\mathrm{CO}_{2}$ emission are the reduction of the fuel consumption and the use biofuels instead of fossil fuels. As depicted in Fig. $9 \mathrm{CO}_{2}$ emissions for blend fuels are higher than diesel fuel. Average $\mathrm{CO}_{2}$ emissions for diesel, B10, B20 and B50 were determined as 7.41, 7.96, 7.96 and $8.14 \%$ (vol.), respectively. The higher $\mathrm{CO}_{2}$ emissions for blend fuels can be attributed to their higher carbon contents and higher fuel consumptions compared to diesel fuel.

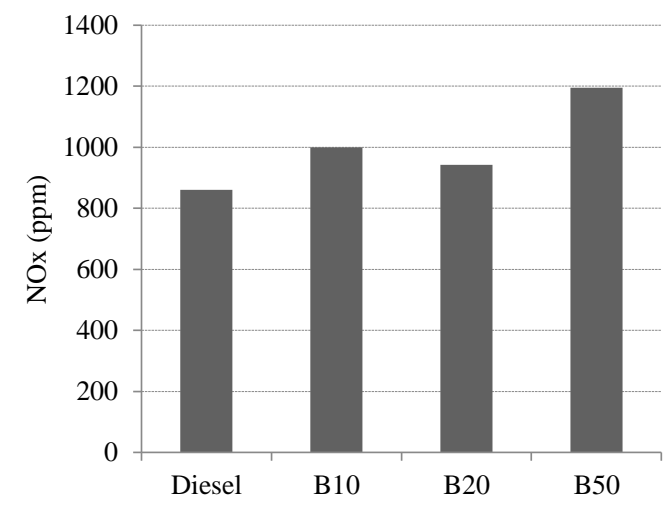

Fig. 8. Comparison of the $\mathrm{NO}_{x}$ emissions for test fuels.

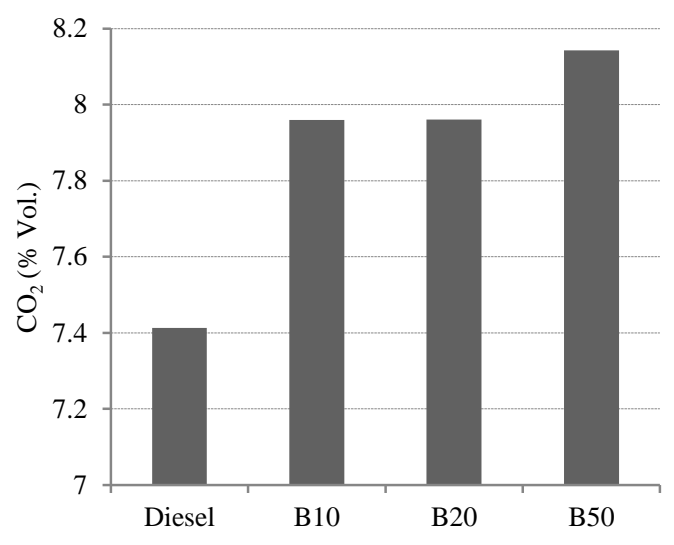

Fig. 9. Comparison of the $\mathrm{CO}_{2}$ emissions for test fuels.

Furthermore, the higher $\mathrm{CO}_{2}$ emissions for blend fuels may originate from their oxygen contents which improve the combustion quality and hence cause an increase in $\mathrm{CO}_{2}$ emissions [5]. In fact, as a part of the carbon cycle, biodiesel does not contribute to the greenhouse effect [13]. When using the biodiesel-diesel blend as fuel the greenhouse effect can be reduced. Hence, the high $\mathrm{CO}_{2}$ emissions for biodiesel-diesel fuel blends should not be evaluated as a disadvantage of them. $\mathrm{O}_{2}$ emission for test fuels is shown in Fig. 10. As seen in the figure blend fuels gave less $\mathrm{O}_{2}$ emission than diesel fuel. Average, $\mathrm{O}_{2}$ emission for diesel, B10, B20 and B50 was determined as $9.56,8.60,7.53$ and $7.35 \%$ (vol.), respectively.
In spite of oxygen content of blend fuels, the engine emits less $\mathrm{O}_{2}$ emission by using them. The reasons of this may be more carbon atom converted to $\mathrm{CO}_{2}$ with blend fuels. The result is compatible with variation of $\mathrm{CO}_{2}$ emissions.

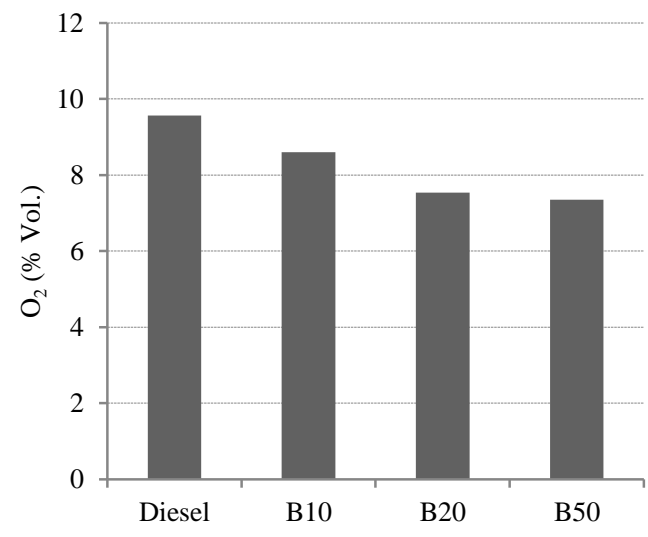

Fig. 10. Comparison of the $\mathrm{O}_{2}$ emissions for test fuels.

\section{CONCLUSIONS}

In this study, performance and emissions of a single cylinder, direct injection diesel engine fueled with corn oil methyl ester-diesel fuel blends were investigated experimentally and the results were compared for each test fuel usage. The obtained results show that B20 and B50 gave lower engine torque and higher brake specific fuel consumption than diesel fuel. However, it is determined that by using B10 there were not big differences between engine torque and brake specific fuel consumption when compared to diesel fuel. Blend fuels gave higher brake thermal efficiency than diesel fuel and the maximum average brake thermal efficiency obtained with B10 as $38.95 \%$. Comparisons of the emissions demonstrated that blend fuels emitted more $\mathrm{HC}, \mathrm{NO}_{x}$ and $\mathrm{CO}_{2}$ emissions when compared to diesel fuel. But it is observed that lower $\mathrm{CO}$ and $\mathrm{O}_{2}$ emissions for blend fuels, generally. Consequently, B10 blend fuel can be substituted for diesel fuel in the tested diesel engine without any engine modification. Moreover, slight higher emissions for B10 are negligible or they can be reduced by after -treatment system.

\section{REFERENCES}

[1] S. Sensoz, D. Angin, and S. Yorgun, "Influence of particle size on the pyrolysis of rapeseed (Brassica napus L.): Fuel properties of bio-oil," Biomass Bioenergy, vol. 19, pp. 271-279, 2000.

[2] E. Alptekin, M. Canalci, A. N. Ozsezen, A. Turkcan, and H. Sanl1, "Using waste animal fat based biodiesel-bioethanol-diesel fuel blends in a DI diesel engine," Fuel, vol. 157, pp. 245-257, 2015.

[3] F. Bob, L. Sabine, R. Marcela, W. Barry, and T. Carrie. (July 2015). EU Biofuels Annual 2015. [Online]. Available: http://gain.fas.usda.gov/Recent\%20GAIN\%20Publications/Biofuels\% 20Annual_The\%20Hague_EU-28_7-15-2015.pdf

[4] M. Canakc1 et al., "Determination of performance and combustion characteristics of a diesel engine with canola and waste palm oil methyl esters," Energy Conversion and Management, vol. 52, pp. 108-116, 2011.

[5] H. Sanl et al., "Effects of waste frying oil based methyl and ethyl ester biodiesel fuels on the performance, combustion and emission characteristics of a DI diesel engine," Fuel, vol. 159, pp. 179-187, 2015.

[6] M. A. Obed et al., "Analysis of blended fuel properties and engine performance with palm biodiesel-diesel blended fuel," Renewable Energy, vol. 86, pp. 57-69, 2016. 
[7] R. Behçet et al., "Comparison of exhaust emissions of biodiesel-diesel fuel blends produced from animal fats," Renewable and Sustainable Energy Reviews, vol. 46, pp. 157-165, 2015.

[8] M. Gülüm and A. Bilgin, "Density, flash point and heating value variations of corn oil biodiesel-diesel fuel blends," Fuel Processing Technology, vol. 134, pp. 456-464, 2015.

[9] W. W. Pulkrabek, Engineering Fundamentals of the Internal Combustion Engine, Prentice Hall, New Jersey, 1997.

[10] C. W. Yu, S. Bari, and A. Ameen, "A comparison of combustion characteristics of waste cooking oil with diesel as fuel in a direct injection engine," Proceedings of the Institution of Mechanical Engineers, Part D: Journal of Automobile Engineering, vol. 216, no. 3, pp. 237-243, March 1, 2002.

[11] C. Öner and S. Altun, "Biodiesel production from inedible animal tallow and an experimental investigation of its use as alternative fuel in a direct injection diesel engine," Applied Energy, vol. 86, pp. 2114-2120, 2009.

[12] A. N. Ozsezen and M. Canakc1, "The emission analysis of an IDI diesel engine fueled with methyl ester of waste frying palm oil and its blends," Biomass and Bioenergy, vol. 34, pp. 1870-1878, 2010.

[13] N. B. C. Ahouisssoussi and M. A. E. Wetzstein, "A comparative cost analysis of biodiesel, compressed natural gas, methanol, and diesel for transit bus systems," Resource Energy Economics, vol. 20, pp. 1-15, 1997.

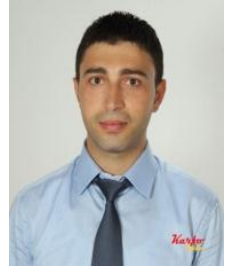

Abdülvahap Cakmak received his MSc degree in mechanical engineering from Karadeniz Technical University, Trabzon, Turkey in 2014. He is currently a $\mathrm{PhD}$ student at the same university and also he is working as a lecturer at Ondokuz Mayıs University, Samsun, Turkey. His research topics are internal combustion engine, energy and exergy analysis and biodiesel.

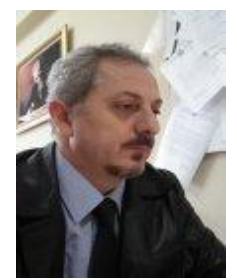

Atilla Bilgin received his master's degree in 1988, and $\mathrm{PhD}$ degree in 1994 from Karadeniz Technical University in Turkey. He is working at Karadeniz Technical University as a professor doctor. His areas of interest are combustion, fuels, engines, computational fluid dynamic, exergy analysis, thermodynamic analysis. 